\title{
The Hidden Dimension of the Language of Corporations in America and Spain: Perspectives for Inter-legal Communications
}

\author{
María Ángeles Orts Llopis \\ University of Murcia \\ mageorts@um.es
}

\begin{abstract}
Starting from Edward T. Hall's assumptions regarding the cultural dimension as the 'hidden dimension' of communication, this study tries to highlight the fact that legal culture vastly influences legal interaction and, hence, varies from system to system. The translation of Company Law from American Legal English into Spanish consists of an exercise in inter-legal communication, as the translator must be aware of the culturally different ways in which the corporate world is contemplated, from the point of view of both the Common Law and the Spanish Continental systems. Through a detailed analysis of the peculiarities of corporate legislation in these different systems that takes into consideration cultural variance, a discussion on the possibility of inter-legal communication is established. In addition, an account of the mercantile terminology belonging to each peculiar legal country is supplied, aimed at explaining how the two different legal systems envision different ways to establish business relationships and identify their constituents linguistically.
\end{abstract}

\section{Introduction: The hidden dimension}

Language, like many other human activities, is a product of culture. There are not one, but many models of cultural knowledge; a range of culturally-shared schematised systems that exist side by side with other cultural systems which encase other subsystems in their turn, 
as encountered in the different scopes of human experience. By the same token, these schematizations are reinforced and perpetuated through language, as the tool that orders the way in which we arrange our experience of the world.

The present work is an attempt to explain the role of cultural schemas in intercultural communication, and specifically in what has been termed inter-legal communication, which that takes place through the mutual interpretation and application of two, or more, legal traditions. More concretely, we will work within the boundaries of what Edward T. Hall $(1959,1966)$ labelled 'the hidden dimension', the notion of space and distance, as an approach to decipher the way in which the American and Spanish legal systems organize their corporate law, in addition to explaining the possibilities of their mutual translation. In this paper, I will speculate on the possibility of explaining the law of corporations in Spanish and its translation into the legal discourse of American law in the light of some of Hall's statements on the role of space in intercultural communication. Hall is mostly associated with proxemics, namely the study of human use of space within the context of culture. I will, therefore, show how Hall's proxemics, as a hidden dimension of communication, can affect the way in which inter-legal communication takes place.

Despite the fact that, occasionally, Hall's paradigms have been accused of being in the terrain of conjecture, they have actually had a profound impact on studies of intercultural communication. There have been enlightening and influential publications on the cultural dimension of organizational behaviour since Hall's work, and names like Mole (1998), Trompenaars (1997) and Klopf (1991) spring to mind, to mention just a few. Especially important is Geert Hofstede's work $(1980,1991)$ on the culture-determined differences in international comparative management and organization, which claims to have "uncovered the secrets of entire national cultures" (1980: 44). Hofstede's work has been both widely quoted (Sondergaard, 1994) and thoroughly contested (McSweeney, 2002) by European Social Scientists. Therefore, his findings, like Klopf's, will remain at stored knowledge patterns employed in the writing process of this article, inasmuch as they are inspired by Hall's work on proxemics. Still, the latter's work will actually be the main background paradigm for study, while Mole's and Trompenaars's research and findings will occupy only a portion of my final reflections on corporations in both the Common law and the Continental law cultures. Be that as it may, I hope my study will cast some further light upon the way in which I think some cultural schematizations are reinforced and perpetuated through language in each legal system, posing frequent problems of interpretation and subsequent translation in the field of corporate law

\section{The Hidden Dimension}

In The Silent Language (1959), Edward T. Hall said: "Experience is something man projects upon the outside world as he gains it in its culturally determined form". Communication, like many other human activities, is culture-bound. As such, it cannot be described or understood without reference to the external world. In the context of human 
exchange, the degree in which we accomplish communicative effectiveness marks the success of our negotiating interactions, as well as the accomplishment of social ends (Holland and Quinn, 1997). However, of all the cultural schemas, the one that rules human existence per se is law. Law is an ideological artefact: it is the most important social accord in democratic societies, and governs with the highest directive force every society worldwide. Institutions such as corporations constitute a legal product, in the same way that contracts and many other artificial constructs -wills, marriages, torts- through which society arranges the official rules of the game of coexistence, are also the product of social agreement. Nevertheless, there is not one, but many legal models, which change from culture to culture. Also, these models have changed in the course of history, and have played a part in political and economic variations. Legal models are likely to be more static in some cultures, more pliable in others, depending on an array of conditions of evolution that frame them as unique and peculiar to each legal tradition. Additionally, the way in which legal models communicate, with one another and within themselves, has much to do with the cultural milieu in which those traditions take place.

Present theories on intercultural communication are extraordinarily indebted to Edward T. Hall. The Hidden Dimension (1966) was Hall's exploration of the cultural phenomena of space, including the invisible boundaries of territoriality, personal space and the multisensory spatial perceptions. Hall believes that space speaks to us as loudly as words, and that, paradoxically, our interpretation of it is outside our awareness. He argues that differing cultural frameworks for defining and organizing space, which are internalized in all people at an unconscious level, can lead to serious failures of communication and understanding in cross-cultural settings. Those who question the validity of Hall's proxemic theory by the presumed lack of thoroughness and vigour of his reported research, usually relegate it to the category of conjecture. Still, Hall's taxonomies, as well as being the inspiration of today's studies on corporate culture, have also had a significant impact in communication theory, where they inspired research on spatial perception that continues to this day (Niemeir, Campbell and Dirven 1998).

\section{An approach to the Spanish and American mercantile traditions}

A contextual, cultural encasement of legal behaviour has a formidable significance for translation and/or contrastive discourse analysis considerations. As a cognitive activity, legislative ruling acts through language, since it is not by chance that law has been defined as a profession of words (Mellinkoff, 1963). And, as law, like language, is the product of local convention, it has its roots and develops in a specific community throughout history, through the usage that its members make of it. Consequently, neither a thorough contrastive discourse analysis, nor an accurate translation of legal texts between Spanish and American English is possible unless the sources of each system, their configuration and their rules of interpretation -in short, their legal traditions- are considered. As Sarèeviæ (1997: 13) states, 
Due to differences in historical and cultural development, the elements of the source legal system cannot simply be transposed into the target legal system. As a result, the main challenge to the legal translator is the incongruence of legal systems (Šarèeviæ, 1997: 13).

In fact, the complexity of a legal translation, Sarèeviæ later adds (2003) depends on the affinities between the systems where the source and target languages are generated, rather than in the lack of distance between the languages themselves.

The basic traits of mercantile law in the United States and Spain are as dissimilar as might be expected from two systems springing from different legal traditions: civil law, based mainly upon codification, and common law, based mainly upon case law with some degree of legislation. As Duro (2005: 637) declares:

Dos maneras distintas de pensar la realidad no pueden por menos que dar como resultado dos modelos diferentes de organizar jurídicamente la sociedad que la habita y le da forma, así como dos talantes, dos trasuntos, dos estilos dispares de plasmar por escrito [......] la materia escrita atrapadora de la realidad.

Indeed, the Spanish system is heir to the Roman tradition of codes, and one of the members of the civil law family. Spain, like most countries in Europe, suffered a process of legal reconstruction and re-codification as early as the 16th and 17th centuries, but especially through the 18 th and $19^{\text {th }}$ centuries, when Roman and Canon Law were integrated in the European jus commune. The result of the development from the times of Justinian is a compact body of rules, where, according to Miguel Duro, there is little life beyond codes (Duro, 2005: 620, my translation). This body of rules is made up of the Código Civil ('Civil Code'), Código Penal ('Criminal Code') and the Código de Comercio ('Commercial Code'), the role of case law and custom being of a comparatively minor importance,.

As Enrique Alcaraz points out in several of his studies on legal English and Spanish $(1994,2000,2001,2002)$, as opposed to the Continental systems, where law is based on legislation and codes -scrutinised in a very general way and wide scope - when applying law to life, the Common law system is based upon jurisprudence or case law rather than upon legislation, and codes are non-existent at the level of Federal law, with the exception of the Uniform Commercial Code of the United States, regulating the buying and selling of merchandise.

In spite of these facts, it is true that there are two realities that bring these two systems closer together. First, there is the fact that, as is to be expected, the sources of the Spanish law merchant are roughly our Commercial and Civil Code, as well as some specific legislation. But codes also rule in the US, as individual states have the power to promulgate laws relating to the creation, organization and dissolution of corporations. There has also been a significant component of Federal corporation law since Congress passed the Securities Act of 1933, which regulates how corporate securities are issued and sold.

Apart from this common legislative aspect, the universality of Merchant law has to be considered. "The phenomenon of commercial exchange spreads worldwide and goes beyond cultures and frontiers, being shaped by progress and evolution" (Duro, 1997: 13, 
my translation).

This international leaning makes commercial law different from any other aspect of juridical systems at large, and brings corporate culture and law closer as globalization advances. The presence of American and Spanish businesses in both countries is a fact, as the entrepreneurship of their people has opened up these two markets to international business opportunities. Accordingly, "in the light of their unique characteristics, each country must develop their cross-cultural communication skills to define their expectations and ensure that their goals are met" (Del Pozo, 2003: 117). It is a fact that both the American and the Spanish markets -which have been closely linked from the historical point of view and share sets of cultural and educational values- must understand each other in order to work together.

\section{Inter-legal communication and the role of space}

As stated above, this paper deals with the language of corporations under the Spanish legal system and its transposition to the American one, in the light of Hall's theory of proxemics. My purpose in doing so is to attain a better understanding of the presence or absence of equivalence between the systems regarding the translation of some major words. In doing so, the notion of space is handled here in its least physical, biological sense and its most abstract one. This implies that the spatial concept of proximity is taken as a starting point from which to describe the relationships and norms that regulate business institutions and their members in the context of Spanish corporate law, and how they compare to the American system.

As regards Hall's findings on the cultural dimension of communication, his most famous innovation has to do with the definition of the informal or personal spaces that surround individuals. The prime directive of proxemic space is that we may not come and go everywhere as we please. There are cultural rules and biological boundaries -explicit as well as implicit; and subtle limits to observe everywhere. He defines the intimate space as the closest 'bubble' of space surrounding a person. Entry into this space acceptable only for the closest friends and intimates, and at the person's will. Secondly, Hall's 'personal distance' -eighteen inches- marks the outer edge of our territorial bubble, where we lose the sense of body heat and all but the most powerful of odours, and only ritualized touch is typical. Then, the social and consultative spaces are those in which people feel comfortable conducting routine social interactions with acquaintances as well as strangers. Finally, public space is the area of space beyond which people will perceive interactions as impersonal and relatively anonymous. Cultural expectations about these spaces vary widely. In the United States, for instance, people engaged in conversation will assume a social distance of roughly four to ten inches, but in many parts of Europe the expected social distance is approximately half of that. In fact, according to Hall's studies, the United States is a 'noncontact' culture. In Hall's view, the ego of the American culture extends approximately a foot and a half out from their body, which breeds an aversion to casual 
touch and resentment towards spatial intrusion. In contrast, Hall claims that Mediterranean cultures, the Spanish amongst them, have given evidence of being contact people. They touch more, position themselves closer, face each other more directly, and hold mutual gaze longer than non-contact subjects. Later, Hofstede, following Hall's seminal work, powerfully describes 'power distance' as one of the dimensions that identifies national culture, defining it as "the extent to which the less powerful members of organizations and institutions like the family expect and accept that power is distributed unequally" (1991: 519).

In my study, however, I will be dealing with the legal systems involved taking into account the features that categorize them either as 'contact' or 'noncontact' legal traditions. The latter is to reveal social and/or impersonal -as well as relatively anonymousinteractions amongst the different kinds of business associations and/or their members from the way these are verbalized; the former is bound to disclose whether the terminology deployed reveals intimate and/or personal-casual relationships amongst such associations and their members. This categorization is carried out with a view to determining the kind of inter-legal relationships that can be established between the systems, for the ultimate purpose of translating their main corporate lexicon.

\section{Some data about Spanish and American corporate law}

To begin with, let's analyse the Spanish law of companies generally. Business associations are dealt with under the Law of Sociedades Mercantiles, or 'Mercantile Companies', as embodied in the Código Civil ('Civil Code') 1889; Código de Comercio ('Code of Commerce'), 1885; Ley de Sociedades de Responsabilidad Limitada ('Law of Limited Responsibility Companies Act'), 2/1995 and the Decreto Legislativo ('Legislative Decree') $1564 / 1989$.

Sociedades, also called empresas, are viewed, at large, as voluntary associations of people under the same denomination, sharing a common fund, money or property for profit, made up of their contributions. As we can see in Tables I and III in the appendix, the terms sociedad mercantil and empresa comprise not only corporations, but other business associations that, incidentally, are not necessarily deemed as such under American Law. Actually, according to Spanish law, sociedad and empresa are allembracing terms that define virtually any kind of legal business association with lucrative purposes. Sociedades are divided into personalistas ('personalist') and capitalistas ('capitalist') depending on their 'element'. 'Personalist' companies are those in which the determining element, or cause, of association is the physical person itself; 'capitalist' those in which it is the capital contributed by the members which constitutes such an element or cause. Ostensibly, these two classes are evenly distributed. In practice, only one type of empresa, the SA or Sociedad Anónima ('anonymous company') has the features to become a truly capitalist one, since the Limitada, or $S L$ is considered a mixed type of corporation, having peculiar features of its own, even if theoretically it is categorized as being also of 
the capitalist kind. Additionally, empresas may be individual or social, depending on the number (one or several, respectively) of members.

On the contrary, American law does not register (or 'incorporate') all the business associations or companies, only Limited or Public corporations are allowed to register. A corporation, like an 'anonymous company', is a legal 'person' that has standing to sue and be sued, as distinct from its stockholders. The legal independence of a corporation prevents shareholders from being personally liable for corporate debts and its legal person status gives the business perpetual life. The word 'corporation' comes from the Latin corpuscorpora, meaning body. Translating this term, in the area of mercantile law, for the Spanish terms corporación would be a blatant semantic error, as the latter has the general, common meaning given to the word by the Oxford English Dictionary, that is, 'a group of people', i.e.,: a group of people authorised to act as an individual, but does not convey the sense given in English business law. Gardner's Dictionary of Modern Legal Usage (1995) clarifies:

At common law, the technical legal term for an entity having legal personality is corporation. The word company could refer to a partnership or other unincorporated association of persons. In current usage, however, company almost always refers to an incorporated company, i.e., a corporation (Gardner: 1995, 225).

By the same token, translating the Spanish sociedad mercantil as 'society' amounts to a similar inaccuracy of correspondence, as the latter has no business character in English -either American or British- but is a term, as the Oxford Companion to Law defines, for the aggregate of persons living together in a more or less ordered community and for the whole complex of relations of man with his fellow-men, and is normally connected to unincorporated associations like friendly societies, bodies incorporated under statute (like literary and scientific institutions) and private clubs.

Incidentally, the most common translation of 'corporation' and 'company' in Spanish is usually either sociedad or empresa. Despite this fact, the latter terms, particularly empresa (with a very wide sense in Spanish, also including the abstract concept of 'enterprise' or 'venture', a project or initiative) fall short of explaining the fact that under Spanish law all the business associations within the legal framework are sociedades or empresas, possess legal status and must be incorporated in the Registro Civil (the Register of Companies), with the exception of the Spanish sole proprietor (empresario individual), whose incorporation is optional. Hence, they can effectively be labelled as 'companies' or 'corporations' from the very moment in which they acquire such a legal status, which is always the case. Under the American law, as in English law, business associations must at least possess limited liability to be considered real corporations; the rest of the associations, even if sometimes defined as companies, do not qualify as such. 


\section{Spatial relationships in Spanish and American corporate law}

All of these considerations take us back to Hall's statements on space, and contact and noncontact cultures. The fact that these 'personal' questions take place in the Spanish law is, in my view, an indicator of the proximity of relationships in the legal system in which they exist. Indeed, most of the companies have a strong personal component, being classified ion terms of the people belonging to it and the relationships they establish. The most striking example is the Spanish sole proprietor, the empresario individual, whose legal entity is recognized as being the same as its owner, and who is not obliged but may register, being explicitly advised to do so by law, in order to benefit from the advantages that are provided when incorporated, such as the publicity and legal status it acquires. All the remaining business forms, either capital or personal in character, must be compulsorily registered, subsequently becoming a legal entity different from that of the members that integrate it. Even in $S L s$, the restricted transfer of shares, which depends upon the agreement of shareholders, introduces a personal question that is not unheeded by Spanish law and turns them into a mixed type of company. In fact, the capital in SLs is divided into participaciones, a term different from acciones, issued by the $S A$ s. The nuance between the 'personal', intimate, character of participaciones is lost in English, which translates both terms as 'shares'. In fact, the concept of participación is, indeed, very dissimilar, under the Spanish law, to that of acción, the former conveying a private, restrictive notion of ownership -requiring the consent and consensus of the partakers as a whole within the Sociedad Limitada- that is lost in the latter, which accepts the public partaking in the holding of shares in a number of ways, such as their private issue or their flotation on the Stock Exchange. Also, this legal system accepts any kind of association for lucrative purposes as having the rank of company and incorporates them, notwithstanding their liability. Incidentally, the 'anonymous company' takes the adjective from Latin, sin alma or sin nombre, 'without a soul', 'without a name', separating this type of business association as one of a kind, and the only social, noncontact one. The sociedad anónima does not posses any personal component, but is defined by capital contributions and the anonymity of its membership, of which the number is unrestricted, as happens with the American corporation.

On the other hand, American law does not consider personal questions at all, but the social, impersonal element is stressed. Minimum capital for incorporation is not required for any business form (which is prescriptive in the case of Spanish law corporations), but limited liability -the civil responsibility to respond in case of financial collapse- marks the boundary between mere businesses and actual corporations. Unlimited liability associations are just concerns, not being commonly referred to as companies, and do not have legal entity or independence. On the other hand, incorporated forms are those which can be considered legal persons and can be properly called corporations, having to be registered, or incorporated. Relationships in American law could be described as taking place at a non-contact level, either at the social or consultative space where routine interactions take place (in the case of sole owners or partnerships of various kinds), or at 
the public space where interactions are impersonal or anonymous, as happens with corporations.

This impersonal aspect is increased in the USA by the plurality of the system. Indeed, there is not one, but manifold bodies of corporate law, as many as there are States, which compete against one another. This fact makes corporate law very diverse, explaining how a corporation may lose its legal entity when removed from the State where it was initially constituted, as corporations are legal persons only in the State where they are incorporated, and also in those States that recognize such a status. What is more, the Corporate Charter, which constitutes and registers a new corporation and is comprised of the Articles of Incorporation and Articles of Agreement, must be signed by the Secretary of State for the State where that corporation is to be created. This is a very different method from that used in Spain, where sociedades undergo a legal process of registration, valid nationwide, very similar to the signing of a deed, a baptism that takes place through the signature of a public instrument in front of a notary.

\section{Corporations in US and Spain: spatial differences}

As stated above, the Spanish Sociedad Anónima, or $S A$, is the closest equivalent to the American public corporation, whereas the limited corporation in USA is comparable to the Spanish Sociedad Limitada or SL. Both of them, $S A$ and Public Corporation, have limited liability, a definite legal persona, no limitations on the transfer of shares and, consequently, an unrestricted number of members. Still, there are internal differences between these business organizations in both countries, attributable to differences of corporate culture.

Ostensibly, in the corporation of both countries there exists a separation between the ownership, which is unrestricted in number, and the control of the company, tangible in the existence of the 'Board', as the organ that represents shareholders, (the Spanish Consejo de Administración). The Board is made up of the President and Vice-Presidents (the Spanish Presidente del Consejo and the Consejeros, respectively) and its existence is justified by the very division between sheer proprietorship -represented by the Consejerosand the management and day-to-day running of the business, which is in the hands of the executive team of the company, the Spanish Directores de Departamento , or Directors in the USA. The powers of the Board are of the supervisory kind, and daily decisions involving execution of tasks and managerial decisions are left in the hands of those specialist Directors, hired by the company and theoretically with no shareholding status, unless so provided by constitutory rules of the company. They are led by the CEO, a member of the Board with mixed attributions, both supervisory and executive, called the Senior Vice-President and Chief Executive Officer, to give him his full title. The American $\mathrm{CEO}$ is the Consejero Delegado or Director Gerente in Spain.

However clear the equivalence between corporate roles in Spain and America may be, studies about business culture patterns in Europe and the USA unveil internal differences, unapproachable at first sight. Trompenaars and Hampden-Turner (1998), define several 
broad types of corporate culture, according to the cultural preferences in the way employees relate to one another and to superiors, the vertical or hierarchical system of authority within the corporation, as well as the employees' general views of its goals and purposes, together with the role they play in the attainment of those goals. These authors position Spanish corporate patterns -along with countries like Italy and Greece- as belonging to the 'family culture', a personal, power-oriented and hierarchical type of business organization where the leader is regarded as a caring father who knows better than his subordinates. It is a culture more interested in intuitive than rational knowledge, more concerned with the development of people than with deployment or utilization (1998:165), a characterization that is in harmony with Hall's description of Spain as a contact culture. In contrast, America's corporate culture is defined as belonging to the 'guided missile' type: egalitarian, impersonal and task-oriented. This is an individualistic kind of culture, allowing for a varied range of people to work with each other on a temporary basis (1998: 174 ), where leadership is typically undertaken by teams or project groups. It is also characterized as neutral, in tune with the description made above of America as a noncontact corporate culture, a culture where affection and mutual commitment are out of place.

Furthermore, also in this line of thought, Mole (1998) points out that the traditional Spanish family company is "built on the concept of personal hierarchy". He speaks about an organization where the ideal leader is the parental figure of a benevolent autocrat, and strategies are based on intuition and business sense, rather than on systematic study. On the other hand, Mole talks about the American corporation, a cultural environment where organisations exist independently of their members and power resides with the CEO, who exercises it through a transparent, rigorously defined and meticulously reported web of senior executives. In this type of corporation, professionalism is demonstrated by a calculated, minutely assessed efficiency in problem-solving and there is an antipathy towards intuitive decisions.

As stated above, differences in corporate culture breed differences in organizational behaviour within them. Consequently, even if we have suggested that the Sociedad Anónima is the most non-contact phenomenon in the Spanish landscape of business associations, it is still true that this organization exists within a 'contact' type of corporate culture. Accordingly, the Spanish corporation is affected by the lack of distance and personal hue that, at large, characterises business associations in the Iberian Peninsula. Therefore, despite the similarity of corporate organigrams in both countries, America and Spain, and the fact that translation between organizational roles can be accomplished somewhat cleanly, there are still proxemic differences that have to be understood to carry out an optimum development of inter-legal relationships, only possible through cultural competence. 


\section{Conclusions. The possibility of inter-legal communication in corporate law}

Inter-legal communication is not only possible, but imperative in the area of corporate law . As the world grows smaller and the economic frontiers fade away, it becomes necessary for companies to set up business in other countries, different from those in which they originated. The American economy is interested in Spain as a friendly, hospitable European country, with whom it shares some common roots. Similarly, as the Spanish economy expands, many companies feel the need to settle in one of the major markets in the world, the American one. When business institutions seek to communicate in the mercantile environment of both countries, such communication becomes hindered, unless the awareness of their cultural differences is achieved.

In my work I have tried to demonstrate that Hall's theories may be a useful as a taxonomy to be deployed to convey the notion of the existence of cultural barriers that must be overcome in order to attain mutual understanding. The concept of space in commercial relationships provides a useful tool to analyse the existence of basic differences of structure and organization in the corporate law of Spain and the United States. The transnational character of business today has had its consequences, namely, on the one hand, the changes that Spanish corporate law is undergoing to adapt to EU regulations, and on the other, the flexibility to be adopted by American companies that set up businesses abroad. All of these tend to blur the fundamental differences in corporate patterns, assumptions and expectations.

Still, failing to heed those differences in the way that each country envisions the legal arrangement of business and their norms of operation could result, if not embarrassing, at least dangerously confusing in the process of inter-legal communication.

\section{References}

Alcaraz Varó, Enrique (1994 and 2000): El inglés jurídico: Textos y documentos. Barcelona: Ariel. . (2000): El inglés profesional y académico. Madrid: Alianza Editorial. . (2002): El español juridico. Barcelona: Ariel.

Alcaraz Varó, Enrique et al. (2001): El inglés jurídico norteamericano. Barcelona: Ariel. Bender, Matthew (ed.) (2003): Doing Business in Spain. Lexis Nexis.

Del Pozo, Manuel (2003): "Management within two cultures: Bridging international business between American and Spanish managers". In George C. Hall, ed., Doing Business in Spain. Madrid: The Commercial Embassy Publications.

Duro, Miguel (1997): "La sociedad anónima en Estados Unidos o la angustia del traductor en España". Trans 2: 9-19.

. (2005): Introducción al Derecho ingles. La traducción jurídica ingles-español y su entomo. Madrid: Edisofer, SL.

Erdozain López, José Carlos and Rodrigo Bercovitz Rodríguez-Cano (2004): Código civil. Madrid: Tecnos

García Luengo, Javier et al.(2005): Código de comercio y legislación mercantil. Madrid: Tecnos. 
Garner, Bryan A. (1999): Black's Law Dictionary. St Paul, Minn.: Westgroup.

Hall, Edward T. (1959): The Silent Language. New York: Doubleday

(1966): The Hidden Dimension. New York: Doubleday

Hofstede, Geert (1984): Culture's consequences: international differences in work-related values.

Beverly Hills, CA: Sage.

. (1991): Cultures and organizations: software of the mind. London: McGraw-Hill, 1991.

Holland Dorothy and Naomi Quinn (1997): Cultural Models in Language and Thought. Cambridge: Cambridge University Press.

Klopf, Donald (1987): Workbook for Intercultural Encounters: The fundamentals of intercultural communications. Englewood, CO: Morton Publishing Company.

Mellinkoff, David (1963): The Language of the Law. Boston: Little Brown Co.

Merryman, J.H. 1978. "Major legal traditions in the contemporary world". In Merryman and Clark, eds, Comparative Law:Western European and Latin American Legal Systems. Cases and Materials. New York: Bobbs-Merril.

Mole, John (1998): Mind your Manners. Managing Business Cultures in Europe. London: Nicholas Brealey Publishing.

Niemeir, Susanne, Charles P. Campbell and Renee Dirven (eds.) (1989): The Cultural Context in Business Communication. Philadelphia: John Benjamin Publishing.

Simpson, John A. and Edumnd Simon Christopher Weiner (eds.) (1989): Oxford English Dictionary, 2nd edition. Oxford: Clarendon Press.

Šarèeviæ, Susan (1997): Approaches to Legal Translation. The Hague: Kluwer Law International.

Sondergaard, Mikael (1994): "Hofstede's consequences: A study of reviews, citations and replications". Organization Studies 15(3): 447-456.

Sweeney, Bernard (2002): "Hofstede's model of national cultural differences and their consequences: a triumph of faith-a failure of analysis". Human Relations 55(1): 89-118.

Trompenaars, Fons and Charles Hampden-Turner (1998): Riding the Waves of Culture. London: Nicholas Brealey Publishing.

Walker, David M. (ed) (1980). The Oxford Companion to Law. Oxford: Clarendon Press.

\section{APPENDIX 1 \\ DIVISION OF EMPRESAS OR SOCIEDADES MERCANTILES IN SPAIN. DIVISION OF BUSINESS ASSOCIATIONS IN THE USA.}

1) TABLE I. DIVISION ONE. SPAIN.

\begin{tabular}{|l|l|l|l|}
\hline $\begin{array}{l}\text { SOCIEDADES } \\
\text { PERSONALISTAS } \\
\text { (Unlimited liability) }\end{array}$ & $\begin{array}{l}\text { Empresario individual/ } \\
\text { Autónomo } \\
\text { (Sole proprietor) }\end{array}$ & $\begin{array}{l}\text { Sociedad } \\
\text { colectiva } \\
\text { (Partnership) }\end{array}$ & $\begin{array}{l}\text { Sociedad } \\
\text { comanditaria } \\
\text { (Limited } \\
\text { Partnership) }\end{array}$ \\
\hline $\begin{array}{l}\text { SOCIEDADES MIXTAS } \\
\begin{array}{l}\text { Limited Liability / Restriction } \\
\text { in the transfer of shares. } \\
\text { (Mixed personalist/capitalist } \\
\text { factors) }\end{array}\end{array}$ & $\begin{array}{l}\text { Sociedad Limitada } \\
\text { (Limited Liability } \\
\text { Company, } \\
\text { Closed Corporation) }\end{array}$ & & \\
\hline
\end{tabular}




\begin{tabular}{|l|l|}
\hline SOCIEDADES & $\begin{array}{l}\text { Sociedad Anónima } \\
\text { (Corporation/Join Stock } \\
\text { CAPITALISTAS } \\
\text { Limited liability }\end{array}$ \\
\hline
\end{tabular}

2) DIVISION TWO. SPAIN.

EMPRESAS INDIVIDUALES: Empresario Individual (Incorporated or not) EMPRESAS SOCIALES: The rest. (Incorporated)

3) TABLE II. DIVISION OF BUSINESS ASSOCIATIONS IN USA.

\begin{tabular}{|l|l|l|l|}
\hline $\begin{array}{l}\text { UNLIMITED: } \\
\text { NOT } \\
\text { INCORPORATED }\end{array}$ & Sole proprietor & $\begin{array}{l}\text { General } \\
\text { Partnership }\end{array}$ & $\begin{array}{l}\text { Limited } \\
\text { Partnership }\end{array}$ \\
\hline $\begin{array}{l}\text { LIMITED: } \\
\text { INCORPORATED }\end{array}$ & $\begin{array}{l}\text { Limited } \\
\text { Liability } \\
\text { Corporation }\end{array}$ & $\begin{array}{l}\text { Public } \\
\text { Corporation }\end{array}$ & \\
\hline
\end{tabular}

\section{ANNEX 2}

TABLE III. ON SOCIEDADES MERCANTILES/BUSINESS ASSOCIATIONS IN BOTH COUNTRIES.

\begin{tabular}{|c|c|c|c|c|c|}
\hline 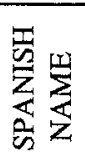 & $\begin{array}{l}\text { EMPRESARIO } \\
\text { INDIVIDUAL }\end{array}$ & $\begin{array}{l}\text { SOCIEDAD } \\
\text { COLECTIVA }\end{array}$ & $\begin{array}{l}\text { SOCIEDAD } \\
\text { COMANDITARIA }\end{array}$ & $\begin{array}{l}\text { SOCIEDAD } \\
\text { LIMITADA, } \\
\text { SRL, SL }\end{array}$ & $\begin{array}{l}\text { SOCIEDAD } \\
\text { ANÓNIMA } \\
\text { SA }\end{array}$ \\
\hline 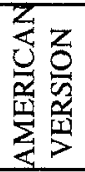 & $\begin{array}{l}\text { Sole proprietor, } \\
\text { owner, trader }\end{array}$ & $\begin{array}{l}\text { General/ } \\
\text { Simple } \\
\text { Partnership }\end{array}$ & Limited Partnership & $\begin{array}{l}\text { Limited Liability } \\
\text { Corporation }\end{array}$ & $\begin{array}{l}\text { Corporation/ } \\
\text { Joint-stock } \\
\text { corporation }\end{array}$ \\
\hline 事是导 & $\begin{array}{l}\text { US: } \\
\text { Not company } \\
\text { SPAIN: } \\
\text { Sociedad }\end{array}$ & $\begin{array}{l}\text { US: } \\
\text { Not company } \\
\text { SPAIN: } \\
\text { Sociedad }\end{array}$ & $\begin{array}{l}\text { US: } \\
\text { Not company } \\
\text { SPAIN: } \\
\text { Sociedad }\end{array}$ & $\begin{array}{l}\text { US: } \\
\text { Company } \\
\text { SPAIN: } \\
\text { Sociedad }\end{array}$ & $\begin{array}{l}\text { US: } \\
\text { Company } \\
\text { SPAIN: } \\
\text { Sociedad }\end{array}$ \\
\hline 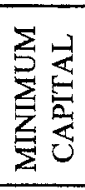 & $\begin{array}{l}\text { SPAIN: Not } \\
\text { required } \\
\text { USA: Not } \\
\text { required }\end{array}$ & $\begin{array}{l}\text { SPAIN: Not } \\
\text { required } \\
\text { USA: Not } \\
\text { required }\end{array}$ & $\begin{array}{l}\text { SPAIN: Not required } \\
\text { USA: Not required }\end{array}$ & $\begin{array}{l}\text { SPAIN: } 3,005 \\
€ \text { required } \\
\text { USA: Not } \\
\text { required }\end{array}$ & $\begin{array}{l}\text { SPAIN: } \\
60,101 € \\
\text { required } \\
\text { USA: Not } \\
\text { required }\end{array}$ \\
\hline
\end{tabular}




\begin{tabular}{|l|l|l|l|l|l|}
\hline & $\begin{array}{l}\text { SPAIN: } \\
\text { Unlimited }\end{array}$ & $\begin{array}{l}\text { SPAIN: } \\
\text { Unlimited }\end{array}$ & $\begin{array}{l}\text { Mixed in both } \\
\text { countries. socios } \\
\text { colectivos, general } \\
\text { partners and socios } \\
\text { comanditarios, } \\
\text { limited partners }\end{array}$ & $\begin{array}{l}\text { SPAIN: } \\
\text { Limited, capital } \\
\text { in } \\
\text { participaciones } \\
\text { USA: Limited, } \\
\text { capital in shares }\end{array}$ & $\begin{array}{l}\text { SPAIN: } \\
\text { Limited, capital } \\
\text { in acciones } \\
\text { USA: } \\
\text { Limited, capital } \\
\text { in shares }\end{array}$ \\
\hline Unlimited & $\begin{array}{l}\text { SPAIN: Optional } \\
\text { incorporation }\end{array}$ & $\begin{array}{l}\text { SPAIN: } \\
\text { Obligatory } \\
\text { incorporation }\end{array}$ & $\begin{array}{l}\text { SPAIN: Obligatory } \\
\text { incorporation }\end{array}$ & $\begin{array}{l}\text { SPAIN: } \\
\text { Obligatory } \\
\text { incorporation }\end{array}$ & $\begin{array}{l}\text { SPAIN: } \\
\text { Obligatory } \\
\text { incorporation } \\
\text { USA: Not } \\
\text { incorporated }\end{array}$ \\
USA: & $\begin{array}{l}\text { USA: Not } \\
\text { incorporated }\end{array}$ & $\begin{array}{l}\text { Uncorporated } \\
\text { USA: } \\
\text { Obligatory } \\
\text { incorporation }\end{array}$ \\
\hline
\end{tabular}

